\title{
A new species of the genus Steneotarsonemus Beer (Actinedida: Tarsonemidae) from Egypt
}

\author{
N. A. Omar \\ Institute of Efficient Productivity, Zagazig University, Zagazig, Egypt
}

\begin{abstract}
ireneotarsonemus zaheri sp. nov. (Acari :Tarsonemidae) was described from females and males collected from leaves if sesame, Sesamum indicum L. and sugar beet, Beta vulgaris L. plants in El-Khatara region, Sharkeia Governorate, Egypt.
\end{abstract}

Key Words: Steneotarsonemus zaheri sp. nov., sesame, sugar beet, description, Egypt.

\section{INTRODUCTION}

Species of the genus Steneotarsonemus Beer are ahytophagous mites, specialized on monocotyledon -lants (Lindquist, 1986; Ochoa et al., 1991b; Smiley $\therefore$ al., 1993; Almaguel et al., 2000). Only two species of this genus, Steneotarsonemus furcatus De Leon and Steneotarsonemus concavuscutum Lofego \& Gondium have been reported from coconut, ocos nucifera L. damaging its fruits. The first species occurred in Central America and Brazil Ochoa et al., 1991a, Navia et al., 2005), while the second was recorded in Brazil (Lofego \& Gondium, 2006). Lin and Zhang (2005) described iteneotarsonemus (Neosteneotarsonemus) ramus from Poa litorosa on Tagua Bay, Auckland Island; $\therefore$ (Mahunkacarus) mayae was found under leaf sheaths and on flower panicles of Dracophllum strictum Hook in Awakina; S. (Steneotarsonemus) ipirifex (Marchal) from ryegrass and pasture soil in Palmerston North and The Glen, New Zealand. Lin et al. 2009, described Steneotarsonemus Steneotarsonemus) saccharum collected from saccharum officinarum L. in Guangdong, China.

In Egypt, Zaher (1986) reported Steneotarsonemus sayedi Zaher \& Kandeel from soil under bamboo at Demiatta, Egypt.

The used terminology followed Lindquist (1986) and the mean measurement for allotype and paratypes is given in millimicron.

\section{Steneotarsonemus zaheri sp. nov. (Figs., $1 \& 2$ )}

\section{Diagnosis:}

This species differs from others in the genus by having three pairs of pores located on the opithosomal segment $\mathrm{D}$ and the more subcircular idiosoma .

\section{Adult female (Fig. 1):}

Body $225 \mu$ long and $159 \mu$ at widest part.

Gnathosoma: Subcircular, dorsal apodeme distinct. Setae $c h$ and $v m$ smooth. Palpus short and robust, with two short subequal smooth setae.
Idiosoma:

Dorsum: Dorsal shielding with wide punctuation posterior to propodosoma and segments C and D posterior ends. Posterior shield with anterior margin truncate, covering only base of the gathosoma. Stigmata located somewhat far from the base of seta $v_{l}$. Seta $\mathrm{d}$ is the longest dorsaly and slightly longer than seta $h$. All setae simple and smooth except bothridial sensilla $s c_{l}$, is rounded. Three pairs of pores located on segment $\mathrm{C}$ while segment $\mathrm{F}$ has a single pair.

Venter: Apodeme I wide and Y-shaped with posternal apodeme and not reaching trochanter I; apodeme II hardly reaching prosternal apodeme . Sejugal apodeme reduced, leaving a weak isolated remnant on other side. Apodeme III extending diagonally from proximity of base of seta $3 a$, diffuse and curved on it, reaching posterior to trochanter III. Apodeme IV wide and extending posterolateral of seta $3 b$, reaching the base of trochanter IV.

Poststernal apodeme is absent. Coxisternal setae $1 a$ inserted behind apodeme me; $2 \mathrm{a}$ behind apodeme II; $3 a$ near anterior end of Apodeme III; $3 b$ middle of apodeme IV.

Legs: Number of setae (solenidia in parentheses) on trochanter, femur, genu, tibia and tarsus, respectively: $\operatorname{leg} \mathrm{I}: 0-4-4-6(1)-7(1)$; $\operatorname{leg}$ II: 0-3-3-4-4(1); leg III: 0-4-4-4; leg IV: 0-2-2. All setae smooth. Tibiotarsus I with an obvious claw; legs II and III each with a drum-shaped empodium.

Adult male (Fig., 2):

Body $183 \mu$ long and $97 \mu$ at widest part.

Gnathosoma: Subcircular, dorsal apodeme conspicuous. Setae $c h$ and $v m$ smooth. Palpus are similar to female.

\section{Idiosoma:}

Dorsum: Propodosomal shield trapezoidal. Dorsal setae simple and smooth; seta $v_{\text {, the longest }}$ dorsal. Seta $v_{l}>s c_{2}>c_{1}=c_{2}=d>v_{2}=f=s c_{1}$. 


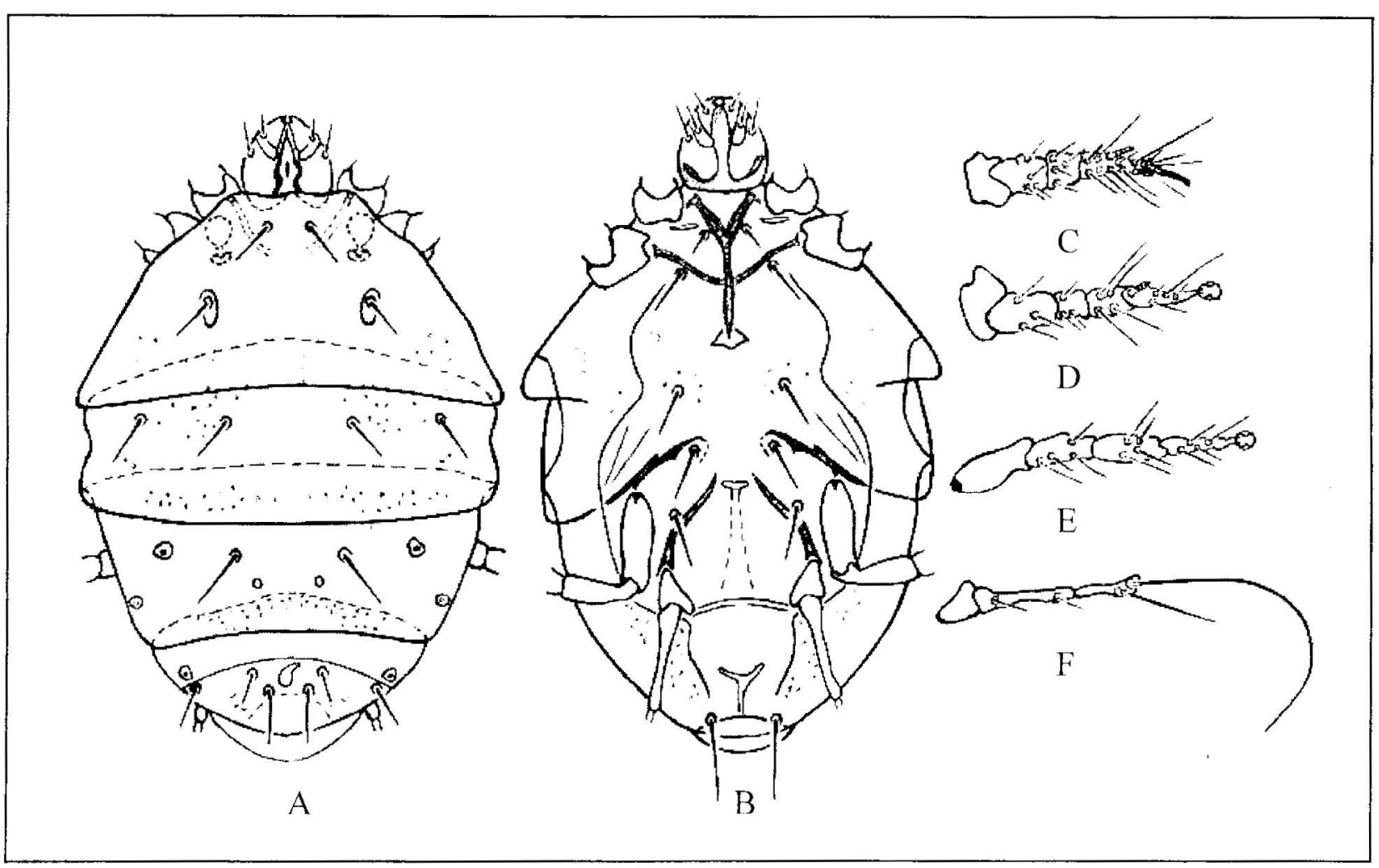

Fig. (1): Steneotarsonemus zaheri sp. nov., Adult female., A. dorsum, B. venter. (C-F) legs I - IV. respectively.

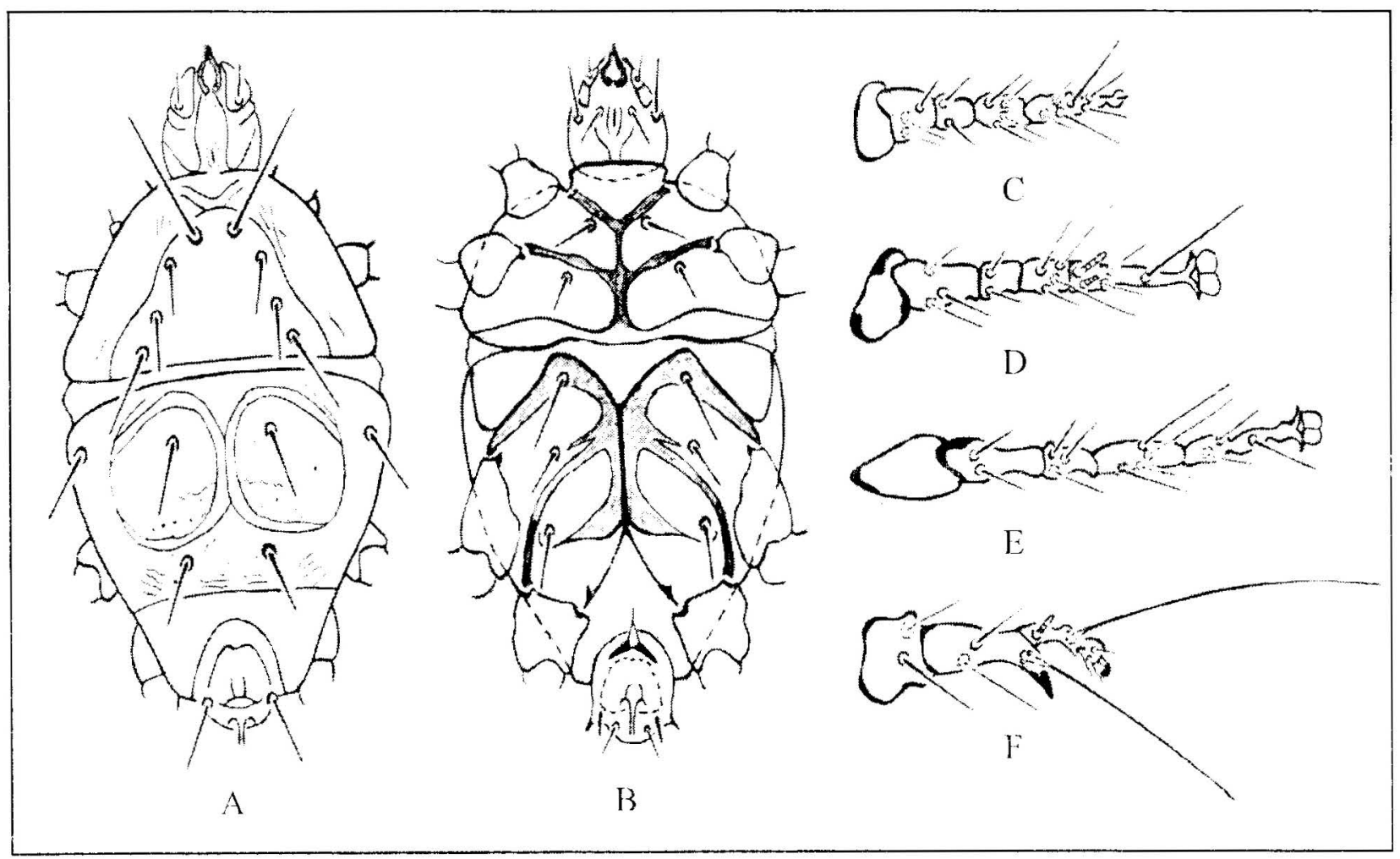

Fig. (2): Steneotarsonemus zaheri sp. nov., Adult male, A. dorsum. B. venter, (C-F). Legs I-IV, respectively. 
Venter: Coxisternal seta la behind middle of apodeme I: seta $2 a$ behind $2 / 3$ of apodeme II; seta $3 a$ near middle of apodeme III and seta $3 b$ near anterior third of apodeme IV. Apodeme I fused with anterior end of prosternal apodeme; apodeme II fused with prosternal apodeme. Poststemal apodeme thin and fused with sejugal apodeme. Sejugal apodeme broad and fused with poststernal apodeme. Poststernal apodeme widening posteriorly. Lines of fusion between coxae III and IV with venter of idiosoma conspicuous; apodeme III wide and curved; spodeme IV thin.

Legs: Leg IV robust. Number of setae (solenidia in parentheses) on trochanter, femur, genu, tibia and tarsus, respectively: leg I: 0-3-2-4-6; leg II: 0-3-2-4-3(2); leg III : 0-2-3-4-3; leg IV: 2-3-4(1)

Type specimens:

Holotype: Adult female, infesting sesame, E1- Khatara region, Sharkeia Governorate, Egypt, deposited in the collection of Inst. of Efficient Productivity, Zagazig University.

Allotype: Adult male, with the same data of holotype, deposited in the collection of Inst. of Ffficient Productivity, Zagazig University.

Paratypes: Several adult females and males from the same region on sesame and sugar bect plants.

\section{ACKNOWLEDGMENT}

The author is grateful to Dr. $\backslash$ M. M. H. Kandeel, Prof. of Acarology, Institute of Efficient Productivity, Zagazig University, Egypt who kindly dentilied the new species and criticized the manuscript.

\section{REFERENCES}

Almaguel, L.; Hernández, J.; Torre, P. de la : Santos.
A.; Cabrera, R. I.; Garcia, A.: Rivero. L.E.; Báez, L.: Cáceres, I. and Ginarte, A., 2000. Evaluatión del comportamiento del ácaro Steneotarsonemus spinki (Acari: Tarsonemidae) en los estudios de regionalización desarrolados en Cuba. Fito sanidad, 4: 15-19.

Lin, Jian - Zhen and Zhang, Zhi-Qiang. 2005. New Zealand species of Steneotarsonemus Beer (Acari: Tarsonemidae). Zootaxa, 1028: 1- 22.

Lin, Jian-Zhen; Chen, Jian-Wen and Zhang, YanXuan, 2009: A new species of Steneotarsonemus Beer from sugarcane in Guangdong, China (Acari: Tarsonemidae). Systematic \&Applied Acarology 14: 225-235.

Lindquist, E.E., 1986. The world genera of Tarsonemidae (Acari: Heterostigmata). a morphological, phytogenetic, and systematic revision, with a reclassification of family-group taxa in the Heterostigmata. Memoris of the Entomological Society of Canada, 136: 1-517.

Lofego, A.C. and Gondim JR, M.G.C., 2006. A new species of Steneotarsonemus (Acari: Tarsonemidae) from Brazil. Systematic \& Applied Acarology 11: 195-203.

Ochoa, R.; Aguilar, H. and Vargas, C., 199la. Acaros fitófagos de América Central: Guía Ilustrata. Turrialbe. CATIE: $251 \mathrm{pp}$.

Ochoa, R.; Smiley, R. L. and Saunders, J. L., 1991b: The family Tarsonemidae in Costa Rica (Acari: Heterostigmata). Internat. J. Acarol., 17 (1): 41-86.

Smiley, R.L.: Flechmann. C.H.W. and Ochoa, R.. 1993. A new species of Steneotarsonemus (Acari: Tarsonemidae) and on illustrated key to grass-infesting species in the Western Ilemisphere . Internat. J. of Acarology. 19: 87-93.

Zaher, M.A.. 1986. Survey and ecological studies on phytophagous, predaceous and soil mites in Egypt: II (B) Predaceous \& nonphytophagous mites (Nile Valley and Delta): Report of PL. 480 program, USA no. E.G.-ARS-30, Grant no. F. G. EG-139. 567 pp. 